\title{
Influence of type of uniform and days of usage in microbiological contamination of nurses uniform in a university hospital
}

\author{
F Guillen-Grima1 1,2*, A Aguinaga-Perez³ , J Nunez-Cordoba², C Sara ${ }^{2}$ \\ From International Conference on Prevention \& Infection Control (ICPIC 2011) \\ Geneva, Switzerland. 29 June - 2 July 2011
}

\section{Introduction / objectives}

Nurse uniforms can act as a reservoir of infections, with the areas around the pockets, cuffs and aprons the most contaminated. The aim of this study is compare the contamination of Standard nurse's uniform consisted of a dress, pinafore apron with the "scrub dress" type of uniform, as well as to measure the influence of the number of shifts as uniform was used in its contamination.

\section{Methods}

Microbiological cultures were collected from uniforms of 88 nurses (58 using traditional uniform and 30 using scrub dress) in an university hospital, during their work in one month period. Cultures were obtained using Count-tact plates (BioMérieux) plates $(25 \mathrm{~cm} 2)$ The culture media were incubated for five days at room temperature. After the incubation period bacterial count and type of bacteria colonizing the uniform were evaluated by microbiologist. Reading was provide in cfu colony forming units. Student T, and correlation were computed with SPSS v.17.

\section{Results}

The average count was $42,82 \mathrm{fcu} / \mathrm{cm} 2$. There was no differences in the count between both types of uniform. $(\mathrm{P}=0,504)$. There was a positive correlation between the number of days and microbiological count. $(r=0,224$, $\mathrm{P}=0,036)$. The average count was $44,36 \mathrm{cfu} / \mathrm{cm}$ in those nurses using the uniform for 1 or 2 shifts, and $65,20 \mathrm{cfu}$ this difference was statistically significant. $(\mathrm{P}=0,031)$.

${ }^{1}$ Health Sciences, Public University of Navarra, Spain

Full list of author information is available at the end of the article

\section{Conclusion}

There are no differences in microbiological contamination between standard or scrub uniform. The main differences in contamination appeared in those nurses that used the same uniform for more than 2 shifts. Hospital should provided nurses with enough uniforms to change before every shift or at least every 2 shifts.

\section{Disclosure of interest}

None declared.

\section{Author details}

${ }^{1}$ Health Sciences, Public University of Navarra, Spain. ${ }^{2}$ Preventive Medicine, University of Vavarra Clinic, Pamplona, Spain. ${ }^{3}$ Microbiology, University of Vavarra Clinic, Pamplona, Spain.

Published: 29 June 2011

\section{doi:10.1186/1753-6561-5-S6-P317}

Cite this article as: Guillen-Grima et al: Influence of type of uniform and days of usage in microbiological contamination of nurses uniform in a university hospital. BMC Proceedings 2011 5(Suppl 6):P317.

Submit your next manuscript to BioMed Central and take full advantage of:

- Convenient online submission

- Thorough peer review

- No space constraints or color figure charges

- Immediate publication on acceptance

- Inclusion in PubMed, CAS, Scopus and Google Scholar

- Research which is freely available for redistribution 